\title{
Isolation and Characterization of
}

\section{Heparin from Human Lung}

\author{
Dean D. Metcalfe, Robert A. Lewis, Jeremiah E. Silbert, Robert D. Rosenberg, \\ Stephen I. WASSERman, and K. Frank Austen, Departments of Medicine, \\ Harvard Medical School and the Robert B. Brigham Division of the Affiliated \\ Hospitals Center, Inc.; Connective Tissue-Aging Research Laboratory, \\ Veterans Administration Outpatient Clinic and Tufts University School \\ of Medicine; and the Beth Israel Hospital and Sidney Farber Cancer Institute, \\ Boston, Massachusetts 02120
}

\begin{abstract}
A B S T RACT Heparin as measured by azure A metachromasia and anticoagulant activity has been extracted with $1 \mathrm{M} \mathrm{NaCl}$ from ${ }^{35} \mathrm{~S}$-labeled human lung fragments or dispersed human lung cells enriched for mast cells. The ${ }^{35} \mathrm{~S}$-labeled metachromatic material in the $3 \mathrm{M} \mathrm{NaCl}$ eluate from Dowex-1 chromatography of the extract from lung fragments exhibited an average mol wt of 20,000 by Sepharose 4B gel filtration. The ${ }^{35} \mathrm{~S}$-labeled metachromatic material with the charge characteristics of commercial porcine heparin on DEAE cellulose chromatography was entirely heparin by the criteria of resistance to degradation by chondroitin ABC lyase and complete degradation by purified heparinase. Antithrombin affinity chromatography of purified heparin with an anticoagulant activity of $137 \mathrm{U} / \mathrm{mg}$, revealed that the one-third that was bound and eluted had a $273 \mathrm{U} / \mathrm{mg}$ sp act, whereas the unbound activity was $31 \mathrm{U} / \mathrm{mg}$. Thus, the previously observed heterogeneity of commercial porcine heparin for binding to human antithrombin was also observed with human heparin. The mast cell-enriched human lung cell preparations yielded $\left.{ }^{35} \mathrm{~S}\right]$ mucopolysaccharides with an average mol wt of 60,000 by Sepharose $4 \mathrm{~B}$ gel filtration. Approximately $30 \%$ of this fraction was degraded by chondroitin ABC lyase, and the residual $70 \%$ was degraded by purified heparinase. When the chondroitin ABC lyase-resistant fraction was subjected
\end{abstract}

Dr. Metcalfe is the recipient of a National Arthritis Foundation Research Fellowship. Dr. Lewis is the recipient of a Young Investigator Research Grant (HL-21089) from the National Heart, Lung, and Blood Institute. Dr. Rosenberg is the recipient of an American Heart Association Established Investigatorship. Dr. Wasserman is the recipient of Allergic Diseases Academic Award (AI-00254) from the National Institute of Allergy and Infectious Diseases.

Received for publication 17 May 1979 and in revised form 9 July 1979. to alkali degradation the average mol wt was reduced to 20,000 . The calculated human lung mast cell heparin content of 2.4-7.8 $\mu \mathrm{g} / 10^{6}$ cells gave a ratio to histamine on a weight basis similar to that of intact lung fragments, thereby implying that heparin in the lung fragments was largely restricted to the mast cells.

\section{INTRODUCTION}

Commercial heparin obtained from porcine intestine and that obtained from beef lung are comprised of glycosaminoglycans of $\cong 10,000$ and $13,000 \mathrm{~mol} \mathrm{wt}$, respectively (1). The anticoagulant function of heparin depends upon an ability to accelerate antithrombin function $(2,3)$, and resides predominantly in those subfractions with antithrombin-binding activity $(4,5)$. As the antithrombin used for binding was human, the possibility existed that lack of species concordance contributed to the apparent heterogeneity in binding and function observed with porcine heparin $(4,5)$.

Human tissue heparin-like activity, defined only by the presence of anticoagulant function and metachromasia, has been observed in mucopolysaccharidecontaining fractions extracted from lung $(6,7)$, liver (8), skin (9), and blood (10, 11). However, in no instance has the material been assessed for binding to human antithrombin. In the present studies, human lung heparin was isolated and defined by anticoagulant activity, azure A metachromasia, susceptibility to degradation by purified heparinase, and resistance to degradation by chondroitin ABC lyase. The human heparin purified from lung fragments had an average mol wt of 20,000 and approximately one-third bound to human antithrombin, a result analogous to the binding heterogeneity observed with porcine heparin. In addition, heparin with an average mol wt of 60,000 was isolated from dispersed enriched populations of human 
lung mast cells and shown to be composed of 20,000 mol wt glycosaminoglycan side chains.

\section{METHODS}

Whale cartilage chondroitin 4-sulfate, mol wt $25,000-50,000$, shark cartilage chondroitin 6-sulfate, mol wt 40,000-80,000, chondroitin ABC lyase from Proteus vulgaris, and porcine skin hyaluronic acid (Miles Laboratories, Inc., Elkart, Ind.); atropine sulfate, bovine albumin, elastase type I, histamine diphosphate, and porcine intestinal heparin, $170 \mathrm{U} / \mathrm{mg}$ (Sigma Chemical Co., St. Louis, Mo.); Sepharose 4B and Sephadex G-50 (Pharmacia Fine Chemicals, Inc., Piscataway, N. J.); Dowex 1-X2 (100-200 mesh, chloride form) and DEAE-cellulose (Bio-Rad Laboratories, Richmond, Calif.); azure A (Fisher Scientific Co., Fair Lawn, N. J.); carbazole (Eastman Kodak Co., Rochester, N. Y.); carrier-free $\mathrm{H}_{2}{ }^{35} \mathrm{SO}_{4}$ (New England Nuclear, Boston, Mass.); chymopapain, collagenase type II, and deoxyribonuclease type I (Worthington Biochemical Corp., Freehold, N. J.); pronase B grade (Calbiochem-Behring Corp., American Hoechst Corp., San Diego, Calif.); gelatin (Difco Laboratories, Detroit, Mich.); mepyramine maleate (Merck, Sharp \& Dohme, Canada Ltd., Montreal, Quebec); Eagle's basal medium with Hanks' balanced salt solution (Microbiological Associates, Walkersville, Md.); and metrizamide (Gallard-Schlesinger Chemical Mfg. Corp., Carle Place, N. Y.) were purchased from the manufacturers. Antithrombin was isolated from human plasma by DEAE cellulose and heparin-Sepharose affinity chromatography $(12,13)$, and coupled to Sepharose $4 \mathrm{~B}$ by cyanogen bromide activation (14). Approximately $3 \mathrm{mg}$ of commercial heparin were bound per ml of packed gel. Purified heparinase prepared from Flavobacterium heparinum was obtained from Dr. A. Linker (University of Utah, Salt Lake City, Utah) (15).

The standard method of dialysis and concentration of human lung heparin between chromatography steps or before enzyme incubations used $40 \mathrm{vol}$ of distilled water for $18 \mathrm{~h}$ followed by lyophilization; recovery of the heparin as measured by azure A metachromasia was $85-90 \%$. Radioactivity was determined with a liquid scintillation spectrometer (Mark III liquid scintillation system, Searle Radiographics Inc., Des Plaines, Ill.). Histamine was measured by bioassay on the atropinized guinea pig ileum (16).

Total mucopolysaccharide was determined by measurement of uronic acid content (17). During extraction and purification procedures heparin was estimated by change in adsorbance at $\mathbf{5 1 0}$ after formation of a heparin-azure A metachromatic complex with commercial porcine heparin as a standard (18, 19). It required 25-30 times as much chondroitin 4-sulfate, dermatan sulfate, or chondroitin 6-sulfate to equal the metachromasia of heparin under the conditions specified. Thus, the selectivity and sensitivity of the azure $\mathbf{A}$ assay for heparin was appropriate for its use in isolating heparin from the limited amounts of starting material. The anticoagulant activity of heparin was determined by its ability to accelerate the neutralization of thrombin by antithrombin (4).

Labeling and extraction of human lung tissue and human lung mast cells. Normal human lung obtained from the tissue resected during the surgical excision of a carcinoma of the bronchus was cut into $250 \mathrm{mg}$ fragments and washed three times in Tyrode's buffer (20). For radiolabeling, $1 \mathrm{~g}$ of tissue was placed in $2.5 \mathrm{ml}$ Eagle's basal medium with Hanks' balanced salt solution with $0.05 \mathrm{mCi}$ of $\left[{ }^{35} \mathrm{~S}\right]$ sulfate. After incubation for $18 \mathrm{~h}$ at $37^{\circ} \mathrm{C}$ under ambient air with $5.0 \% \mathrm{CO}_{2}$ tension (Hotpack Carbon Dioxide Incubator, Hotpack Corp. Philadelphia, $\mathrm{Pa}$.), the lung fragments were washed three times in Tyrode's buffer and extracted by freeze-thawing six times in $1 \mathrm{M} \mathrm{NaCl}$. Residual lung fragments were treated with
$0.5 \mathrm{M} \mathrm{NaOH}$ for $18 \mathrm{~h}$ at $22^{\circ} \mathrm{C}$ to solubilize remaining glycosaminoglycans by $\beta$-elimination (21).

To obtain mast cells, the human lung fragments were enzymatically digested in a four-step procedure with chymopapain, pronase, collagenase, and elastase $(22,23)$. The dispersed cells obtained at each step were pooled, and the mast cells were concentrated to $40-70 \%$ purity by isopyknic and velocity gradient sedimentation $(24,25)$. The purity was defined by phase microscopy after staining with toluidine blue (26) and by electron microscopy (25). The mast cell-rich cell suspension at a concentration of $5 \times 10^{6}-1 \times 10^{7}$ cells $/ \mathrm{ml}$ was incubated in Eagle's basal medium with Hanks' balanced salt solution with $\left.0.1 \mathrm{mCi}{ }^{35} \mathrm{~S}\right]$ sulfate in a final vol of $5-10 \mathrm{ml}$ for $18 \mathrm{~h}$ at $37^{\circ} \mathrm{C}$ under $5.0 \% \mathrm{CO}_{2}$ tension, washed three times in Tyrode's solution, and extracted by freeze-thawing six times in $1 \mathrm{M} \mathrm{NaCl}$.

\section{RESULTS}

Isolation and purification of heparin from human lung fragments. The extracts from 55,82 , and $200 \mathrm{~g}$ of human lung fragments, designated preparations 1,2 , and 3 , respectively, were each applied directly to a $2 \times 20$-cm column of Dowex-1 equilibrated in $1 \mathrm{M}$ $\mathrm{NaCl}$ and eluted in stepwise fashion with 1,3 , and $4 \mathrm{M} \mathrm{NaCl}(2,27)$. Portions of each fraction were assessed for ${ }^{35} \mathrm{~S}$, protein (28), uronic acid, metachromasia, and anticoagulant activity. The $1 \mathrm{M} \mathrm{NaCl}$ effluent contained more than $99 \%$ of ${ }^{35} \mathrm{~S}$, histamine, and total protein, but was without azure A metachromasia and anticoagulant activity. The material eluted by $3 \mathrm{M}$ $\mathrm{NaCl}$ contained uronic acid, $<0.1 \%$ of the total protein, $<0.003 \%$ of the ${ }^{35} \mathrm{~S}$, and exhibited all of the azure $\mathrm{A}$ metachromasia and anticoagulant activity. Based upon metachromasia, the heparin content in the $3 \mathrm{M} \mathrm{NaCl}$ extract from the three separate lung fragment preparations was $4.5,22.5$, and $44.7 \mu \mathrm{g} / \mathrm{g}$ lung tissue. Histamine content in the $1 \mathrm{M} \mathrm{NaCl}$ effluent in the same three lung preparations was 2,8 , and $20 \mu \mathrm{g} / \mathrm{g}$ lung tissue. The $4 \mathrm{M}$ $\mathrm{NaCl}$ eluate had minimal ${ }^{35} \mathrm{~S}$ and no metachromasia or anticoagulant activity. Treatment of residual lung fragments with $4 \mathrm{M}$ guanidinium chloride and $0.5 \mathrm{M}$ $\mathrm{NaOH}$ failed to yield additional azure A-positive material but did free additional uronic acid-containing materials. A portion of the $3 \mathrm{M} \mathrm{NaCl}$ eluates from Dowex-1 obtained from the three different lung preparations and containing 140,920 , and $4,474 \mu \mathrm{g}$ of heparin by metachromasia, respectively, was filtered in $2 \mathrm{M} \mathrm{NaCl}$ on a $1 \times 60-\mathrm{cm}$ column of Sepharose 4B at a flow rate of $2 \mathrm{ml} / \mathrm{h}$. l-ml fractions were collected, and portions were assayed for ${ }^{35} \mathrm{~S}$, uronic acid, anticoagulant activity, and metachromasia. Heparin, as determined by metachromasia, filtered as a single broad peak, with an estimated average mol wt of 20,000 (Fig. 1). Peak anticoagulant activity corresponded to peak metachromasia. Glycosaminoglycans, as determined by uronic acid content, were found only between fractions 20 and 34, whereas ${ }^{35} \mathrm{~S}$ appeared in two peaks. The initial ${ }^{35} \mathrm{~S}$ 


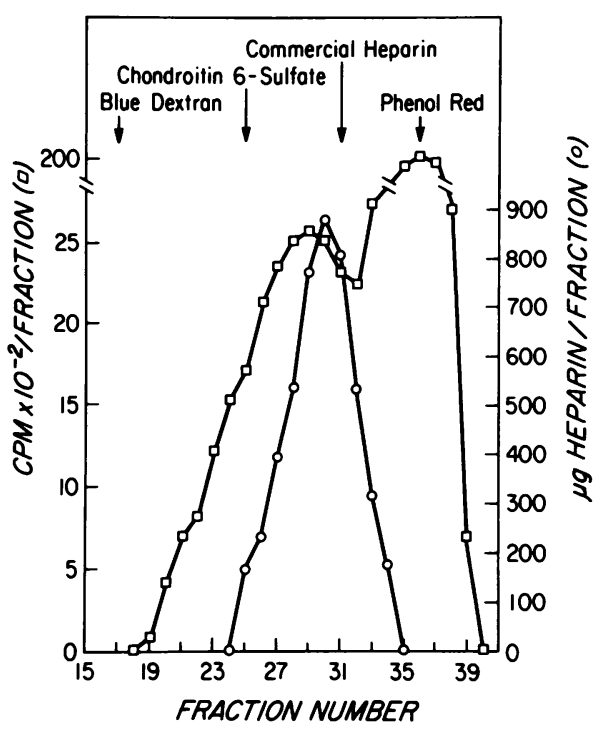

Figure 1 Sepharose 4B gel filtration of human lung fragment mucopolysaccharides obtained in the $3 \mathrm{M}$ eluate from Dowex-1 chromatography of preparation 3 . The positions of blue dextran, chondroitin 6-sulfate (average mol wt $=60,000$ ), commercial heparin (average mol wt $=12,000$ ), and phenol red, which were filtered separately on the same column, are shown.

peak filtered with an average mol wt of 20,000-40,000 and the second, which contained low molecular weight materials, was not further characterized. A pooled sample of the first peak of the $\left.{ }^{35} \mathrm{~S}\right]$ mucopolysaccharides, fractions $20-34$, was treated with $0.5 \mathrm{M} \mathrm{NaOH}$ at $22^{\circ} \mathrm{C}$ for $14 \mathrm{~h}$ to disrupt any xylosyl-seryl proteoglycan bonds (21). After this treatment, the $\left[{ }^{35}\right.$ S]glycosaminoglycans filtered on Sepharose 4B in a single peak that was coincident with metachromasia and uronic acid and had an average mol wt of 20,000 .

A pooled sample of the first peak of the $\left[{ }^{35} S\right]$ mucopolysaccharides (Fig. 1) containing 1,046 $\mu \mathrm{g}$ heparin by azure $A$ metachromasia was incubated with $4 \mathrm{U}$ of chondroitin $\mathrm{ABC}$ lyase in $0.25 \mathrm{ml}$ of $0.25 \mathrm{M}$ Tris buffer, made $0.3 \mathrm{M} \mathrm{Na}$ acetate, $0.25 \mathrm{M} \mathrm{NaCl}$, and $5 \mathrm{mg} / 100 \mathrm{ml}$ bovine serum albumin, $\mathrm{pH} 8.0$, for $90 \mathrm{~min}$ at $37^{\circ} \mathrm{C}$ (enriched Tris buffer) (29); a replicate portion was treated under the same conditions with buffer alone. Both treated and untreated samples were then filtered on a $1 \times 60$-cm column of Sephadex G-50 equilibrated in $\mathrm{H}_{2} \mathrm{O}$ at a flow rate of $3 \mathrm{ml} / \mathrm{h}$, and $1-\mathrm{ml}$ fractions were collected. After exposure to chondroitin ABC lyase, $90 \%$ of ${ }^{35} \mathrm{~S}$ and $25 \%$ of uronic acid-containing material was degraded as indicated by a shift in filtration pattern, while the heparin, as defined by azure A metachromasia, was unaffected (Fig. 2). For preparation 3, the specific activity of the chondroitin ABC lyase-resistant mucopolysaccharides was $4.8 \mathrm{cpm} / \mu \mathrm{g}$ heparin by azure A metachromasia. Preparations 1 and 2 had more radio-

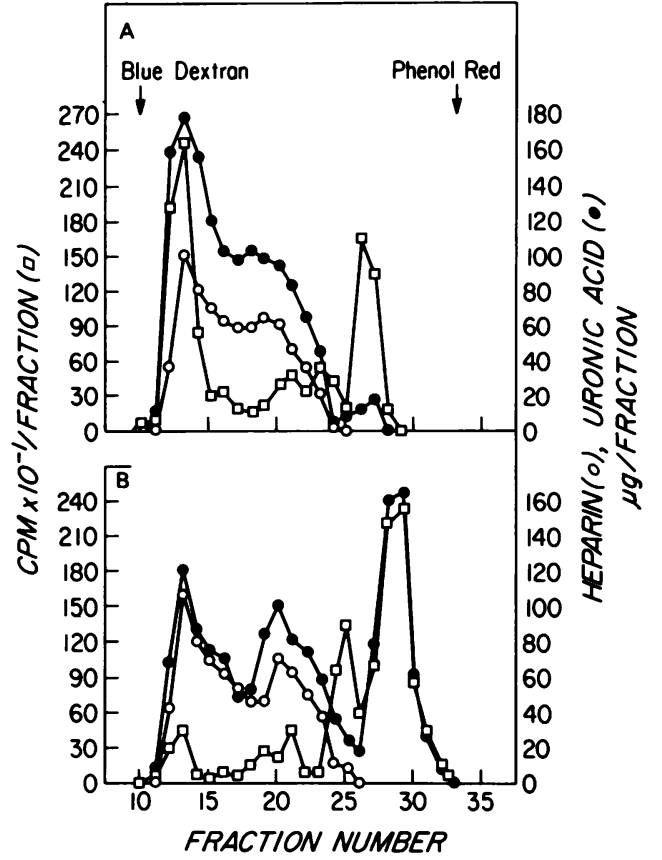

Figure 2 Effect of treatment with chondroitin ABC lyase on Sephadex G-50 gel filtration of human lung tissue mucopolysaccharides obtained from Sepharose 4B filtration of preparation 3. A, shows untreated material and B, the effect of chondroitin ABC lyase degradation. The positions of blue dextran and phenol red, which were filtered separately on the same column, are shown.

activity but less endogenous heparin in the lung extract. A sample from preparation 1 containing 800 $\mathrm{cpm}$ and with a $12 \mathrm{cpm} / \mu \mathrm{g}$ heparin sp act by azure A metachromasia was incubated with $250 \mu \mathrm{g}$ of purified heparinase for $90 \mathrm{~min}$ in $0.1 \mathrm{ml}$ of $0.1 \mathrm{M}$ acetate buffer, $\mathrm{pH} 7.0$, at $30^{\circ} \mathrm{C}$, and a replicate sample was incubated in buffer alone. Degradation was assessed by filtration on a $1 \times 60$-cm column of Sephadex G-50 equilibrated in $\mathrm{H}_{2} \mathrm{O}$ with a flow rate of $2.5 \mathrm{ml} / \mathrm{h}$, and $1-\mathrm{ml}$ fractions were collected. More than $70 \%$ of the heparinasetreated material was degraded when compared to the untreated sample (Fig. 3). This pattern is similar to that obtained when $250 \mu \mathrm{g}$ of commercial heparin was treated in the same fashion.

To isolate the heparin directly, a portion of the $3 \mathrm{M}$ $\mathrm{NaCl}$ eluate from Dowex-1 chromatography of preparation 3 containing $2,092 \mu \mathrm{g}$ of heparin as defined by metachromasia was applied to a $1 \times 5$-cm column of DEAE-cellulose equilibrated in $0.01 \mathrm{M}$ sodium acetate buffer with $0.1 \mathrm{M} \mathrm{LiCl}, \mathrm{pH}$ 5.5. The column was eluted with a logarithmic gradient from 0.1 to $1.0 \mathrm{M} \mathrm{LiCl}$, followed by a second logarithmic gradient from 1.0 to $2.0 \mathrm{M} \mathrm{LiCl}$ (30). Fractions of $2 \mathrm{ml}$ each were collected at a flow rate of $25-30 \mathrm{ml} / \mathrm{h}$, and portions of each were assayed for radioactivity, uronic acid content and 


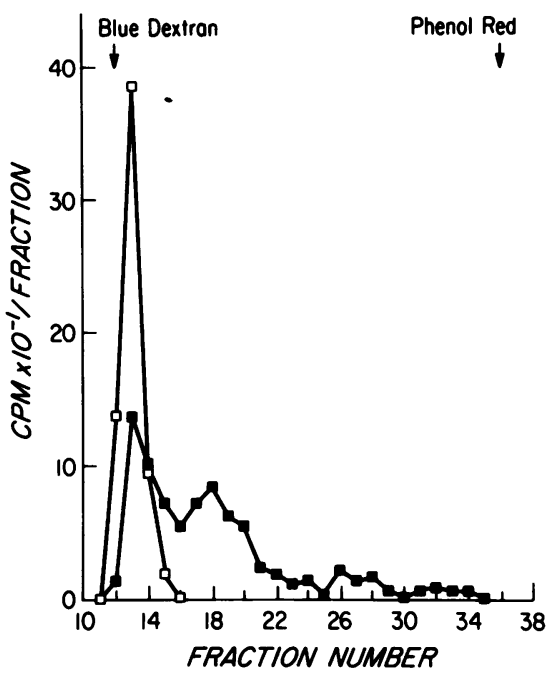

Figure 3 Sephadex G-50 gel filtration of chondroitin ABC lyase-resistant $\left.{ }^{35} \mathrm{~S}\right]$ mucopolysaccharides of preparation 1 before ( $\square$ ) and after ( $\square$ ) treatment with heparinase. The positions of blue dextran and phenol red, which were filtered separately on the same column, are shown.

metachromasia (Fig. 4). The ${ }^{35}$ S-labeled material filtered in two distinct peaks with most appearing coincident with the effluent and the remainder eluting with azure A-positive fractions 87-111. Uronic acid was found in fractions 47-75 and 87-111. 51 $\mu \mathrm{g}$ of $\left[{ }^{35}\right.$ S]mucopolysaccharides by uronic acid, containing $800 \mathrm{cpm}$, from pooled DEAE fractions $47-75$, and $4.4 \mu \mathrm{g}$, containing $100 \mathrm{cpm}$, from pooled fractions $87-111$ were

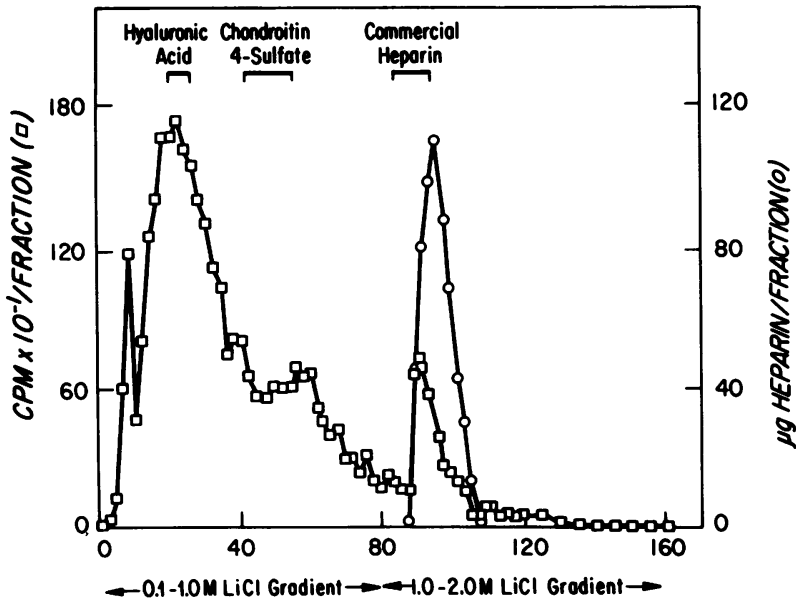

FRACTION NUMBER

Figure 4 DEAE-cellulose chromatography of human lung fragment mucopolysaccharides from preparation 3 contained in the $3 \mathrm{M} \mathrm{NaCl}$ eluate from Dowex-1 chromatography. Determinations in every other tube are shown. The column was previously standardized with chondroitin 4-sulfate (3 mg), commercial heparin ( $3 \mathrm{mg})$, and hyaluronic acid ( $2 \mathrm{mg}$ ). each incubated with $1 \mathrm{U}$ of chondroitin $\mathrm{ABC}$ lyase in enriched Tris buffer for $90 \mathrm{~min}$ at $37^{\circ} \mathrm{C}$. Sephadex G-50 gel filtration of treated and untreated material, performed as described for Fig. 2, showed that $90 \%$ of the ${ }^{35}$ S]mucopolysaccharides from fractions 47-75 were degraded, whereas none was degraded in the pool from fractions 87-111. Based on azure A metachromasia, the specific activity of the heparin in the latter was 4.3 $\mathrm{cpm} / \mu \mathrm{g}$. This material was completely degraded by heparinase under the conditions described for Fig. 3. The total recovery of heparin after Sepharose 4B gel filtration of the original $3 \mathrm{M} \mathrm{NaCl}$ Dowex-l eluate was 75-90\% for three human lung preparations as defined by the chondroitin ABC lyase-resistant, heparinasesensitive, azure A-positive material, and 70 and $74 \%$ in two preparations obtained by DEAE cellulose chromatography and defined by azure A metachromasia.

Specific anticoagulant activity and affinity for antithrombin. The heparin in the azure A-positive peak fractions 87-111 (Fig. 4) was divided into five 5-ml pools consisting of $1 \mathrm{ml}$ from each of fractions 87-91, 92-96, 97-101, 102-106, and 107-111. After dialysis and lyophilization, each pool was assayed for heparin by uronic acid, radioactivity and anticoagulant activity (Table I). Specific anticoagulant activity increased sequentially in the five pools from $27 \mathrm{U} / \mathrm{mg}$ to 179 $\mathrm{U} / \mathrm{mg}$ when compared to a heparin standard of known U. S. Pharmacopeia potency (4), while the specific radioactivity of $\left[{ }^{35} \mathrm{~S}\right]$ heparin/mg was highest in pool 1 (Table I).

Pools 1 and 2 with the lowest functional activity, and pools 3-5 with the highest functional activity were separately combined (Table II). Each composite pool was applied to $1 \times 2-\mathrm{cm}$ Sepharose-antithrombin column equilibrated in $0.1 \mathrm{M} \mathrm{NaCl}$. The columns were washed with three bed volumes of equilibrating buffer, and eluted with $1 \mathrm{M} \mathrm{NaCl}$. Approximately $19 \%$ of the heparin defined by uronic acid content in pools 1-2

TABLE I

Specific Anticoagulant Activity of Human Lung Heparin after DEAE-Cellulose Chromatography: Relationship to Incorporated ${ }^{35} \mathrm{~S}$

\begin{tabular}{ccccc}
\hline $\begin{array}{c}\text { Pool } \\
\text { fraction }\end{array}$ & $\begin{array}{c}\text { DEAE } \\
\text { fractions }\end{array}$ & $\begin{array}{c}\text { Total } \\
\text { heparin* }\end{array}$ & ${ }^{\text {ss } S^{*}}$ & $\begin{array}{c}\text { Anticoagulant } \\
\text { activity* }\end{array}$ \\
\hline & & mg/pool & $c p m / m g$ & U/mg \\
1 & $87-91$ & 0.125 & 5,920 & 27 \\
2 & $92-96$ & 0.164 & 3,600 & 85 \\
3 & $97-101$ & 0.180 & 1,744 & 133 \\
4 & $102-106$ & 0.096 & 1,250 & 169 \\
5 & $107-111$ & 0.056 & 1,750 & 179 \\
\hline
\end{tabular}

* Each value is the mean of three determinations. Counts per minute were determined $3 \mathrm{wk}$ after the data presented in Fig. 4. 
TABLE II

Antithrombin-Sepharose 4B Affinity Chromatography of Human Lung Heparin from DEAE-Cellulose: Determination of Specific Anticoagulant Activity in Bound and Unbound fractions

\begin{tabular}{lcr}
\hline \multicolumn{1}{c}{ Pool fractions } & Heparin* & $\begin{array}{r}\text { Anticoagulant } \\
\text { activity* }\end{array}$ \\
\hline $\begin{array}{l}\text { 1-2 } \\
\text { Initial activity }\end{array}$ & U/mg \\
$\begin{array}{l}\text { After chromatography } \\
\quad \text { Unbound }\end{array}$ & 0.180 & 60 \\
$\quad$ Bound & 0.096 & 8 \\
$\begin{array}{l}\text { 3-5 } \\
\quad \text { Initial activity } \\
\quad \text { After chromatography } \\
\quad \text { Unbound }\end{array}$ & 0.035 & 187 \\
$\quad$ Bound & 0.252 & 137 \\
\hline
\end{tabular}

* Each value is the mean of three determinations.

bound to the antithrombin. After elution with $1 \mathrm{M}$ $\mathrm{NaCl}$ it had a sp act of $187 \mathrm{U} / \mathrm{mg}$ heparin as compared to $8 \mathrm{U} / \mathrm{mg}$ heparin for the material that failed to bind. Approximately $33 \%$ of the heparin defined by uronic acid content in pools $3-5$ bound to the antithrombin and had a specific activity of $273 \mathrm{U} / \mathrm{mg}$ heparin, whereas $31 \mathrm{U} / \mathrm{mg}$ heparin was recovered in material that failed to bind. The material in the wash between the collection of unbound and bound heparin was not quantitated because of dilution and it is assumed that this accounts for the loss of $\cong 20 \%$ of the material applied.

Heparin in mast cell-enriched cell suspensions. The extracts from three different preparations of ${ }^{35} \mathrm{~S}$-labeled dispersed human lung cells of $40-70 \%$ mast cell purity and containing 5.0, 6.4, and $8.0 \times 10^{6}$ mast cells were chromatographed over Dowex-1 in a manner identical to that used to separate human lung fragment mucopolysaccharides from histamine, protein, and free ${ }^{35} \mathrm{~S}$. The $3 \mathrm{M} \mathrm{NaCl}$ Dowex-1 eluate from three preparations contained $1,290,1,800$, and $4,521 \mathrm{cpm}$ of $\left[{ }^{35}\right.$ S]mucopolysaccharides and $13.5,28.2$, and $62.4 \mu \mathrm{g}$ of heparin by metachromasia representing $2.7,4.4$, and $7.8 \mu \mathrm{g}$ of heparin $/ 10^{6}$ mast cells. The $1 \mathrm{M} \mathrm{NaCl}$ Dowex- 1 effluent contained $1.0,2.3$, and $2.8 \mu \mathrm{g}$ of histamine $/ 10^{6}$ mast cells. In contrast, the $3 \mathrm{M} \mathrm{NaCl}$ Dowex-1 eluate from 2.6 $\times 10^{6}$ lung cells consisting of $<4 \%$ mast cells, had no detectable metachromasia and the $1 \mathrm{M} \mathrm{NaCl}$ Dowex-1 effluent had no measurable histamine. The entire $3 \mathrm{M}$ $\mathrm{NaCl}$ Dowex-1 eluate of each of the three mast cell preparations was filtered separately in $2 \mathrm{M} \mathrm{NaCl}$ on a $1 \times 60-\mathrm{cm}$ column of Sepharose $4 \mathrm{~B}$ at a flow rate of $2 \mathrm{ml} / \mathrm{h}$ and $1-\mathrm{ml}$ fractions were assayed for ${ }^{35} \mathrm{~S}$. There was insufficient material to assay fractions by uronic acid content or metachromasia. As shown in Fig. 5A for the

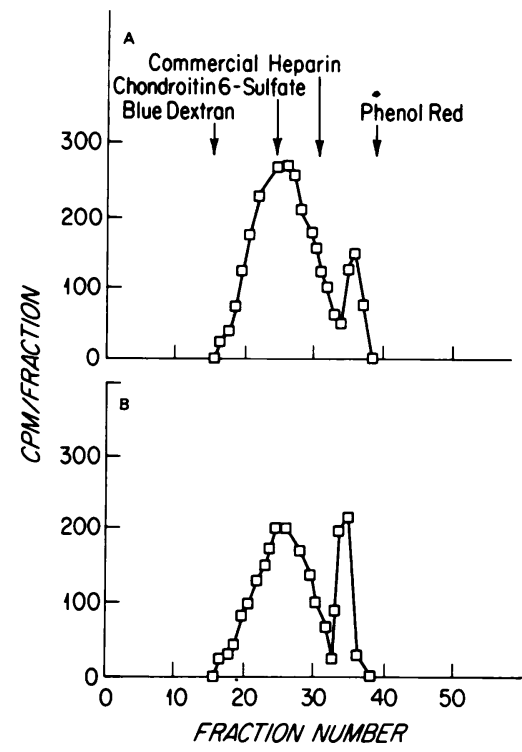

Figure 5 Sepharose 4B gel filtration of $\left[{ }^{35}\right.$ S $]$ mucopolysaccharides in the $3 \mathrm{M} \mathrm{NaCl}$ eluate from Dowex-1 chromatography of the extract from mast cell-rich cell suspensions. $A$, shows untreated material and $B$, the effect of chondroitin ABC lyase degradation.

preparation exhibiting the most radioactivity, the ${ }^{35} \mathrm{~S}$ labeled material presented as a broad peak that preceded a commercial heparin marker and was estimated to have an average mol wt of 60,000 . The second smaller peak of low molecular weight was not characterized further. Fractions 15-34, which contained $\left[{ }^{35}\right.$ S]mucopolysaccharide with an estimated average mol wt of 60,000 , were pooled, dialyzed, and lyophilized. A portion of this pool was treated with $1 \mathrm{U}$ of chondroitin $\mathrm{ABC}$ lyase in enriched Tris buffer for $90 \mathrm{~min}$ at $37^{\circ} \mathrm{C}$. Rechromatography over the same Sepharose 4B columns demonstrated (Fig. 5B) that more than $70 \%$ was resistant to degradation by chondroitin $\mathrm{ABC}$ lyase, and the remainder appeared in a second peak of glycosaminoglycan degradation products.

Chondroitin ABC lyase-resistant material in fractions 15-34 (Fig. 5B) was pooled, dialyzed, and lyophilized. One-third was subjected to $\beta$-elimination with $0.5 \mathrm{M} \mathrm{NaOH}$ and another one-third to degradation with heparinase. When the portion treated with $0.5 \mathrm{M}$ $\mathrm{NaOH}$ for $14 \mathrm{~h}$ at $22^{\circ} \mathrm{C}$ was rechromatographed on the same Sepharose 4B column, a predominant peak containing $74 \%$ of the $\left[{ }^{35} \mathrm{~S}\right]$ mucopolysaccharide filtered with an approximate mol wt of 20,000 , followed by a peak of lower molecular weight. The second one-third was mixed with $250 \mu \mathrm{g}$ of commercial heparin in $0.1 \mathrm{ml}$ of $0.1 \mathrm{M} \mathrm{Na}$ acetate buffer, $\mathrm{pH} 7.0$, filtered on a $1 \times 60$-cm column of Sephadex G-50 in distilled $\mathrm{H}_{2} \mathrm{O}$ at a flow rate of $2.5 \mathrm{ml} / \mathrm{h}$, and fractions of $0.67 \mathrm{ml}$ collected. Fractions 20-49 were pooled, lyophilized, resus- 


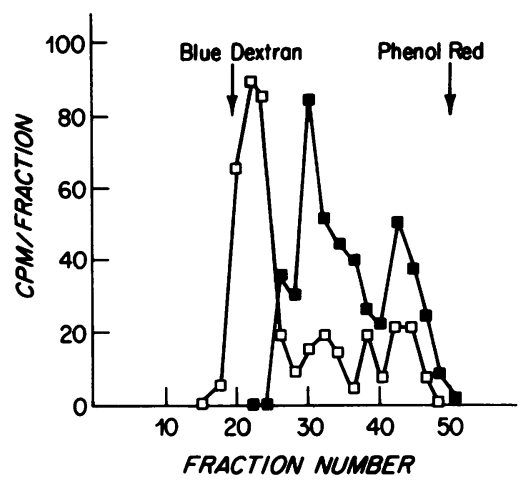

FIGURE 6 Sephadex G-50 gel filtration of chondroitin ABC lyase-resistant mucopolysaccharides obtained by Dowex-1 chromatography and Sepharose 4B gel filtration of the extract from mast cell-enriched cell suspensions before ( $\square$ ) and after (a) treatment with heparinase. The positions of blue dextran and phenol red, which were filtered separately on the same column, are shown.

pended in $0.1 \mathrm{ml}$ of the above buffer and incubated with $250 \mu \mathrm{g}$ of purified heparinase for $90 \mathrm{~min}$ at $30^{\circ} \mathrm{C}$. Chromatography of this reaction mixture showed that the ${ }^{35} \mathrm{~S}$-labeled mucopolysaccharide was degraded when compared to untreated material (Fig. 6). The $250 \mu \mathrm{g}$ of commercial heparin added as an internal standard was also degraded as assessed by a shift of the uronic acid from the excluded to the included fractions.

\section{DISCUSSION}

Human heparin, previously recognized only on the basis of metachromasia and anticoagulant activity (6-11), has been isolated from human lung and characterized in terms of size, charge, enzyme susceptibility, and specific functional activity. Human lung fragments were labeled with ${ }^{35} \mathrm{~S}$ and extracted in $1 \mathrm{M}$ $\mathrm{NaCl}$, and the $\left.{ }^{35} \mathrm{~S}\right]$ mucopolysaccharides were separated from free counts and protein by chromatography on Dowex-1. The metachromatic material in the $3 \mathrm{M}$ eluate fraction exhibited an average mol wt of 20,000 by Sepharose 4B gel filtration (Fig. 1) and the charge characteristics of commercial heparin on DEAE cellulose chromatography (Fig. 4). The glycosaminoglycan heparin isolated by DEAE cellulose chromatography was free of contaminating glycosaminoglycans, as there was no degradation by chondroitin ABC lyase and full degradation of the material by purified heparinase. When two DEAE fractions of this human heparin were subjected to antithrombinaffinity chromatography, the bound and eluted material exhibited a specific anticoagulant activity of 187 and $273 \mathrm{U} / \mathrm{mg}$, whereas the unbound material had an activity of only 8 and $31 \mathrm{U} / \mathrm{mg}$, respectively (Table II). Hence the partitioning of heparin on antithrombin cannot be ascribed to lack of species concordance.
To demonstrate that heparin was associated with mast cells, human lung fragments were enzymatically digested and the dispersed mast cells were concentrated to $40-70 \%(25)$. The $\left[{ }^{35} \mathrm{~S}\right]$ mucopolysaccharides extracted in $1 \mathrm{M} \mathrm{NaCl}$ and eluting from Dowex-1 in 3 $\mathrm{M} \mathrm{NaCl}$ exhibited an average mol wt of 60,000 by Sepharose 4B gel filtration (Fig. 5A). Approximately $30 \%$ of this fraction was degraded by treatment with chondroitin ABC lyase (Fig. 5B), and the residual $70 \%$ was susceptible to degradation by purified heparinase (Fig. 6). As the degradation of heparitin sulfates by purified heparinase during two sequential 24-h digestions yields almost entirely products excluded on Sephadex G-50 (31), the degradation in $1.5 \mathrm{~h}$ to products that are entirely included on Sephadex G-50 gel filtration indicates that the chondroitin $\mathrm{ABC}$ lyase-resistant sulfated mucopolysaccharide was entirely heparin. When the chondroitin $\mathrm{ABC}$ lyase-resistant material was subjected to alkali treatment under conditions known to cleave xylosyl-seryl linkages in proteoglycans, the predominant radiolabeled peak was reduced to an estimated average mol wt of 20,000 . This fact suggests that the mast cell-enriched preparations contain a small proteoglycan with an average mol wt of 60,000 and that the glycosaminoglycan side chains were similar in size to those isolated directly from the human lung fragments. The ratio of histamine to heparin by weight was 1:2.2, 1:2.9, and 1:2.2 for the three human lung fragment preparations and $1: 1.9$, $1: 2.2$, and $1: 3.1$ for the three preparations of dispersed lung cells obtained from additional lung specimens. Since the mast cell is the only defined source of lung histamine, the consistency in these ratios suggests that heparin was derived from the same cell. Basophils have not been observed by electron microscopic examination of dispersed human lung cells, or in the mast cell-enriched preparations (25); further, heparin is not a major mucopolysaccharide of this cell, being absent in guinea-pig basophils (32) and consisting of $<20 \%$ of the mucopolysaccharide obtained from human or rat leukemic basophils $(33,34)$. The content of histamine in human lung mast cells ranged from 1.0 to $2.8 \mu \mathrm{g} / 10^{6}$ cells, as observed previously (25), and of heparin from 2.4 to $7.8 \mu \mathrm{g} / 10^{6}$ cells.

\section{ACKNOWLEDGMENTS}

The authors would like to thank Ms. Judith Litvin for her excellent technical assistance.

This work was supported in part by grants AI-07722, AI-10356, AM-08816, HL-17382, HL-19131, and RR-05669 from the National Institutes of Health, in part by a grant from the Lillia Babbitt Hyde Foundation and in part by the Medical Research Service of the Veteran's Administration.

\section{REFERENCES}

1. Lasker, S. E. 1977. The heterogeneity of heparins. Fed. Proc. 36: 92-97. 
2. Yurt, R. W., R. W. Leid, Jr., K. F. Austen, and J. E. Silbert. 1977. Native heparin from rat peritoneal mast cells. $J$. Biol. Chem. 252: 518-521.

3. Rosenberg, R. D. 1977. Biologic actions of heparin. Semin. Haematol. 14: 427-440.

4. Lam, L. H., J. E. Silbert, and R. D. Rosenberg. 1976. The separation of active and inactive forms of heparin. Biochem. Biophys. Res. Commun. 69: 570-577.

5. Rosenberg, R. D., G. Armand, and L. Lam. 1978. Structure-function relationships of heparin species. Proc. Natl. Acad. Sci. U. S. A. 75: 3065-3069.

6. Horner, A. A. 1977. The concept of macromolecular heparin and its physiologic significance. Fed. Proc. 36: 35-39.

7. Engelberg, H. 1963. Heparin: Metabolism, Physiology and Clinical Application. Charles C Thomas, Publisher, Springfield, Ill. 20.

8. Schmitz-Moormann, P. 1964. Zur biochemie der kohlenhydrate der gesunden menschichen leber. HoppeSeyler's Z. Physiol. Chem. 338: 63-73.

9. Bollet, A. J., D. V. Anderson, and W. F. Simpsen. 1958. The measurement of tissue acid mucopolysaccharides. J. Clin. Invest. 37: 858-863.

10. Astrup, P. 1947. On the determination of heparin in blood plasma and urine. Acta Pharmacol. 3: 165-178.

11. Engelberg, H. 1961. Plasma heparin levels in normal man. Circulation. 23: 578-581.

12. Rosenberg, R. D., and P. S. Damus. 1973. The purification and mechanism of action of human antithrombin-heparin cofactor. J. Biol. Chem. 248: 6490-6505.

13. Damus, P. S., and R. D. Rosenberg. 1976. Antithrombinheparin cofactor. In Enzymology. L. Lorand, editor. Academic Press, Inc., New York. 45: 653-669.

14. Cuatrecasas, P. 1970. Protein purification by affinity chromatography. Derivatizations of agarose and polyacrylamide levels. J. Biol. Chem. 245: 3059-3065.

15. Hovingh, P., and A. Linker. 1970. The enzymatic degradation of heparin and heparitin sulfate. III. Purification of heparitinase and a heparinase from flavobacteria. J. Biol. Chem. 245: 6170-6175.

16. Brocklehurst, W. E. 1960 . The release of histamine and formation of a slow-reacting substance (SRS-A) during anaphylactic shock. J. Physiol. (Lond.). 151: 416-435.

17. Bitter, T., and H. M. Muir. 1962. A modified uronic acid carbazole reaction. Anal. Biochem. 4: 330-334.

18. Jaques, L. B., F. C. Monkhouse, F. C., and M. Stewart. 1949. A method for the determination of heparin in blood. J. Physiol. 109: 41-48.

19. Jaques, L. B., and A. Wollin. 1967. A modified method for the colorimetric determination of heparin. Can.J. Physiol. Pharmacol. 45: 787-794.
20. Tyrode, M.W. 1910. The mode of action of some purgative salts. Arch. Int. Pharmacodyn. Ther. 20: 205.

21. Nicolet, B. H., and L. A. Shin. 1941. The special lability of serine and threonine toward alkali; when in peptide combination. J. Biol. Chem. 140: 685-686.

22. Gould, K. J., J. A. Clements, A. L. Jones, and F. M. Felts. 1972. Dispersal of rabbit lung into individual viable cells: A new method for the study of lung metabolism. Science (Wash. D. C.). 78: 1209-1210.

23. Lewis, R. A., S. I. Wasserman, E. J. Goetzl, and K. F. Austen. 1974. Formation of slow-reacting substance of anaphylaxis in human lung tissue and cells before release. J. Exp. Med. 140: 1133-1146.

24. Pretlow, T. G., and T. G. Cassady. 1970. Separation of mast cells in successive stages of differentiation using programmed gradient sedimentation. Am. J. Pathol. 61: 323-337.

25. Paterson, N. A., S. I. Wasserman, J. W. Said, and K. F. Austen. 1976. Release of chemical mediators from partially purified human lung mast cells. J. Immunol. 117: 1356-1362.

26. Ehrlich, P. 1877. Beitrage zur kenntnis der anilinfarbung en und ihrer verwengung in der mikroskopischen technik. Arch. Mikrobiol. 13: 263-277.

27. Slorach, S. A. 1971. Histamine and heparin release from isolated rat mast cells exposed to compound 48/80. Acta Physiol. Scand. 82: 91-97.

28. Lowry, O. H., N. J. Rosebrough, A. L. Farr, and R. J. Randall. 1951. Protein measurement with the Folin phenol reagent. J. Biol. Chem. 193: 265-275.

29. Yamagata, T., H. Saito, O. Habuchi, and S. Suzuki. 1968. Purification and properties of bacterial chondroitinases and chondrosulfatases. J. Biol. Chem. 243: 1523-1535.

30. Lewis, R. G., A. F. Spencer, and J. E. Silbert. 1973. Biosynthesis of glycosaminoglycans by cultured mastocytoma cells. Biochem. J. 134: 455-463.

31. Linker, A., and P. Hovingh. 1975. Structural studies of heparitin sulfates. Biochim. Biophys. Acta 385: 324-333.

32. Orenstein, N. S., S. J. Galli, A. M. Dvorak, J. E. Silbert, and H. F. Dvorak. 1978. Sulfated glycosaminoglycans of guinea pig basophilic leukocytes. J. Immunol. 121: 586-592.

33. Olsson, I., B. Berg, L. A. Fransson, and A. Norden. 1970. The identity of the metachromatic substance of basophilic leukocytes. Scand. J. Haematol. 7: 440-444.

34. Metcalfe, D. D., S. I. Wasserman, and K. F. Austen. 1979. Isolation and characterization of sulfated mucopolysaccharides from rat basophil leukemia (RBL-1) cells. Biochem. J. In press. 